\title{
When the border educates: Malín Alegria's Sofi Mendoza's Guide to Getting Lost in Mexico (2007)
}

"The U.S.-Mexican border es una herida abierta where the Third World grates against the fist and bleeds"

(Anzaldúa, 1987: 3)

\author{
AMAIA IBARRARAN-BIGALONDO* \\ Universidad del País Vasco / Euskal Herriko Unibertsitatea (UPV/EHU)
}

Received: 16/07/2015. Accepted: 16/02/2016.

\begin{abstract}
The border between the United States and Mexico, since it was first conceived in 1848, has marked the lives of those who live on both of its sides, as well as of those who want to cross it. It has also become the source of a vast array of theoretical and artistic work. Chicano writers have written about it, and so have theorists dealt with its meaning and conceptual implications. The aim of this essay is to observe the way Malín Alegria's Sofi Mendoza's Guide to Getting Lost in Mexico (2007), a novel for young adults, serves as a way for young adults to "evolve a moral conscience" (Scharf, 1980: 101), through a process of "critical witnessing" (López, 2009: 205) of what it means to be on one or the other side of la frontera.
\end{abstract}

KEYWORDS: US-Mexico border, young adult chicano literature, adolescence.

\section{INTRODUCTION}

Borders are lines that separate us from them. Widely read Chicana scholar Gloria Anzaldúa exposed their essence (1987): they are separating lines that mark centrality and marginality, belonging and non-belonging. Borders, thus, are ambiguous spaces, which mark the existence of those on either side and, similarly, define Us and Them depending on the side. In the case of the United States-Mexico border, the frontera marks not only the division between us and

\footnotetext{
*Address for correspondence: Amaia Ibarraran-Bigalondo. Departamento de Filología Inglesa y Alemana, Traducción e Interpretación, Universidad del País Vasco / Euskal Herriko Unibertsitatea (UPV/EHU), Facultad de Letras, Vitoria-Gasteiz, Spain; e-mail: amaia.ibarraran@ehu.eus.
} 
them, here and there, North and South, legal and illegal, but also a big gap between what is now considered the First World and the Third World. This border, in particular, marks a clear separation between two nations with their own cultural and ideological realities. It defines the roles of the two countries, the United States as the target country and Mexico as the country of departure (or the country from and through which most immigrants cross to the United States).

Studies and statistics on the crossings (both legal and 'illegal') ${ }^{1}$ from Mexico to the United States are abundant (Bureau of Transportation Statistics, BTS; Migration Policy Institute, MPI; and others). They show that, of the American crossers, around a third are of Mexican origin and the rest from other South and Central American countries. The increase in the number of illegal crossings today has provoked several ideological as well as physical and spatial issues, one of which is the building of a two-thousand-mile fence between the United States and Mexico after the Secure Fence Act was signed into law in 2006 by President Bush. ${ }^{2}$ This fence, together with the work of the Border Patrol, is aimed as a deterrent to the numerous crossings every year. The post-9/11 policies for defending US boundaries have motivated the militarization of this border in particular. However, as many studies have shown, this fence and the obvious growing military presence in the area are not stopping the crossings but instead are promoting an organized illegal business aimed at passing people from one side to the other by smugglers and coyotes (Spener, 2004). A proven failure, the fence is the materialization of the step taken by President George W. Bush on the War on Terror, which shows conceptual similarities to Operation Wetback that was structured as a response to internal instability during the Cold War in the 1950s. ${ }^{3}$ Moreover, according to sociologist Avi Astor, this geopolitical border (and the fence in particular) establishes a clear ideological position on the part of the US government, which turns the crossers into "illegal aliens", or "bare life" as Giorgio Agamben described the status that these 'illegal' people received during Operation Wetback (in Astor, 2009). Astor defends the idea that the sociopolitical context today is similar to that in the $1950 \mathrm{~s}$, and thus, an organized repatriation movement such as Operation Wetback could reoccur. The border has become essential in the construction of a very particular border identity, and in the reinforcement of US and Mexican national identities. In this sense, in the ironic, contradictory sociopolitical and economic context of a 'bordered globalized' world, scholars such as Jessica Auchter explain that borders have become essential for the construction of nation-states. In the case of the US-Mexico border, the mere existence of this 'untresspassable' line, and the emergence of this new category of humans, "illegal aliens" (Agamben), feed the everyday practices that construct the notion of the state, or what Jessica Auchter calls "statecraft". For her, the fence

[...] is itself a symbol of the will to contain migration, to construct the identity of those situated on both sides, and to impose a will upon the landscape itself. The fence imposes upon the landscape the concept of sovereign territoriality. Before the fence, there is just

(C) Servicio de Publicaciones. Universidad de Murcia. All rights reserved. IJES, vol. 16 (1), 2016, pp. 19-32 Print ISSN: 1578-7044; Online ISSN: 1989-6131 
desert, brush, and land. After the fence, there are citizens, ownership, geography, territory, governance, and enforcement. (2013: 295)

In her words, the US is nourished by the existence of the border, which ultimately needs the 'illegal crossers' because "[ $t$ ] he state is defined by its citizenry and by those who do not fit into the requirements for citizenship. The immigrant, documented or not, is that which is different from the citizen, the constitutive outside to the citizen, the other to the state" (Auchter, 2013: 296), comparable to Kristeva's abject: rejected, but essential for the formation of the self. Similarly, Chicana critic Gloria Anzaldúa refers to los atravesados, transgressors and aliens, whose existence, however, legitimates the power of the "whites and those who align themselves with whites" (1987: 4). In sum, although "alarmist discourse uses images and/or text to suggest problems, fears, or dangers raised by immigration, such as population growth, demographic changes, a lack of assimilation, a break-up of the nation, or the death of the nation" (Chávez, 2003: 255), the US nation-state needs these immigration flows to construct and defend its own existence and to justify its growing fears and anxieties and, thus, the subsequent militarization of the border.

\section{2. (CHICANO/A AND LATINO/A) YOUNG ADULT LITERATURE: EDUCATION THROUGH "CRITICAL WITNESSING"}

Chicano literature and art, voice and mirror of the community's sociopolitical situation over the past last decades, have addressed the issues of immigration, the border and the fence, and its effects in many works. Thus, authors such as Anzaldúa have addressed the existence of the border and immigration, as a reality and a concept, mostly from an adult, cultivated,

philosophical perspective. ${ }^{4}$ In this essay, I discuss the way the border and the two supposedly opposing worlds it constructs is perceived by an adolescent character and deployed in a novel addressed to young adults. The effect immigration (both 'legal' and 'illegal') has on adolescents has been tackled from different perspectives. According to the United StatesMexico Border Health Commission (2009) (in Chávez-Palacios, Blanco \& Graf, 2012: 11), these migrant adolescents face issues in addition to having to leave one's country, such as "low educational attainment, low income, high poverty rates, and lack of health insurance and health care providers" (in Chávez-Palacios, Blanco \& Graf, 2012: 11), which "along with migration and acculturation processes, may lead to anxiety and anxiety disorders among Hispanics" (Chávez-Palacios, Blanco \& Graf, 2012: 11). Generally crossing with their parents, or for family reunification after long parental absences, these young boys and girls must go through the rite of passage that adolescence implies in a strange country that does not even recognize them as 'legal' human beings. 
Literature written for and by young Chicanos and Latinos is increasing and focuses on themes that are prevalent among this target group, such as assimilation, bilingualism, biculturalism, intergenerational/intercultural conflicts, etc. When literature for young Chicanos and Latinos addresses issues of (undocumented) immigration

(Undocumented migration) novels for YAs involve three central antagonistic forces: poverty, physical danger in the crossing, and immigration laws. These forces create conflict and function against the protagonists. They also serve as metaphors for the larger political and social forces and public policies shaping the characters' lives.

The adolescents must overcome poverty by finding employment in America and managing exploitation, they must survive the risks of unauthorized entry, and they must evade the immigration laws that prohibit their unauthorized entry into and employment within the United States. Border enforcement officials personify the immigration laws and usually appear as frightening, undifferentiated characters.

Through these narrative strategies, readers become complicit with the adolescents in resisting poverty, surviving danger, and evading the enforcers of border law. (Cummins, 2013: 63)

However, and before moving into the study of Alegria's novel, a reflection on the mere existence of young adult literature as a literary genre on its own, which has been questioned and discussed by many critics and scholars, should be done. Some authors state that there actually is a body of literature for young adults which comprises what is called Young Adult Literature. These young adults are people in their teens, who are immersed in a profound process of becoming, of shaping and understanding themselves and making sense of the world they live in. This process encompasses both physical and spiritual/emotional/ personality changes which affect not only the way teenagers see and value themselves, but also their relationship with their parents, or other adults who may represent authority, as well as with their peers. The acceptance of their bodies and lives as they are, the discovery of sexuality and other, new ways of relating to people, and in sum, the constant questioning of issues such as "Who am I?" and/or "What is my role in life?", become the core issues that these boys and girls have to deal with during their adolescent years. In this context, the degree of maturity or naïvete of each and every adolescent is not marked by her/his age, but by the way s/he is going through said process and the way s/he overcomes it. Young adult literature, thus, is considered, by many, the body of literature addressed at individuals going through said process, regardless of their age, or in American writer Sylvia Engdahl's words "a teenage novel is one intended for adolescent readers" (1980: 41). However, for others, such as children and adult fiction author Isabelle Holland, adolescent literature is just "whatever any adolescent happens to be reading at any time" (1980: 33).

Despite the diverse interpretations of what young adult literature is or the way it may be defined, there exists a body of literature which is addressed at adolescents and deploys issues 
that concern individuals going through this specific time in a person's life. According to critic Peter Scharf, the relationship of this literary genre and the teenager's development as an individual is directly linked to the adolescents' "evolving moral conscience" (1980: 101). The scholar bases his explanation of said relationship on psychologist Lawrence Kohlberg's Theory of Moral Judgment, ${ }^{5}$ which defines six stages in this development (grouped into the pre-conventional, the conventional and the post-conventional or principled). At each of such stages, different literary themes predominate. Hence, he defines three "types of literature" that illustrate these stages: the literature of social expectations, the literature of social revolt, and the literature of affirmation (Scharf, 1980: 103). Literature for adolescents tackles these issues and represents the adolescent character's rite of moral passage, which usually moves from a state of negation to one of affirmation of values and the self. In this sense, the literature produced for and addressed at young readers fulfills a function, which is to accompany the reader in this process of moral becoming and ultimate self-recognition. For this purpose, as children's literary critic Steve Roxburgh explains, literature for young adults shares some common characteristics:

Most of it is, in the broad sense of the word, mimetic: that is, imitative, rather than fantastic. The setting is the contemporary world. The main characters are, in the ambiguous language of age groups, neither children nor adults, but, rather, adolescents. Situations arise out of home and school life, generally, and involve family and peers. We see the world through the eyes of the youthful protagonists. Perhaps the most significant aspect of contemporary adolescent fiction is its focus on the moments of crisis that are typical of the transitional stage between childhood and adulthood. [...] The "ideal type" of contemporary adolescent fiction focuses on two kinds of crisis, although many related crises are tied to those. The recognition by youth of the breakdown of the traditional values and institutions of the adult world, be it the family, marriage, or parenthood. [...] Related to this, but distinct from it, are novels that deal with growth and burgeoning selfawareness, specifically, consciousness of sexuality. (1980: 142)

In the case of the Chicano and Latino youth, who are oftentimes denied a cultural specific education at schools, the relevance of the body of literature which addresses issues of their concern is essential. The last decades have witnessed the proliferation of writers who directly address a young adult audience. ${ }^{6}$ The individual works of Juan Felipe Herrera, Pam Muñoz Ryan, Luis J. Rodríguez Michele Serros, Gary Soto or Malín Alegria, among others, collections such as Judith Ortiz Cofer's Riding Low Through the Streets of Gold. Latino Literature for Young Adults (2003), or works as Sherry York's Children's and Young Adult Literature by Latino Writers. A Guide For Librarians, Teachers, Parents, and Students (2002), together with the efforts of publishing houses such as Piñata Press (part of Arte Publico Press) are proof of the existence of a vast body of literature which addresses issues that concern young adult Latinos/as. This literary body helps raise what Tiffany Alma López 
denominates acts of "critical witnessing" (2009), as is the case of the novel focus of this essay. In this particular case, the construction of a recognizable-for-young-adults character who is unaware of life in the border, and even of its mere existence, together with her gradual recognition of its reality, is thought to help young adult Chicano/a and Latino/a (and other) readers to became acquainted with this reality in a critical way. As Jamie Campbell Naidoo observes, this kind of observation and experimentation which may arise from the consciousness raising function of a novel "serve as gifts to the imaginative identity development of Hispanic youth" (2011: 14), and thus, help develop their evolving moral conscience, as addressed by Scharf (1980: 101).

\section{LEARNING IN THE BORDER, LEARNING FROM THE BORDER}

Malín Alegria, born and raised in San Francisco by Chicano activist parents and educated at the University of California at Santa Barbara, has written short stories and young adult novels (Estrella's Quinceañera (2006), and a Border Town Series (2012)), for and about Chicano adolescents who are often trapped in the in-betweenness of their Mexican American sociocultural condition. In this essay, I analyze the way the writer uses the issues Cummins pinpointed (a description of poverty, immigration, exploitation, unauthorized entry, etc., as well as life in the United States and Mexico) in the reverse direction (that is, in a North to South movement). Through this act of "critical witnessing" (López, 2009), the author aims at making young readers aware of what 'illegality' implies and of the situation in both sides of the border, in an attempt to 'educate' them about a reality they may choose to ignore. Similarly, I observe the way the idea of "statescraft" (Autcher, 2013), or in this sense 'identitycraft' (the making of identity), for young adult Chicanos/as and Latinos/as goes through the necessary understanding of the reality of the United States and Mexico. In this sense, the novel aims to deploy a clear moral message, which would lead young readers to value and appreciate their past and present, and their complex cultural heritage, and grow a moral conscience (Scharf, 1980: 101) through critical witnessing (López, 2009: 205).

Alegria summarizes the novel as follows:

Even though Sofi Mendoza was born in Mexico, she's spent most of her life in California - the closest she gets to a south-of-the-border experience is eating at Taco Bell. But when Sofi and her friends sneak off for a weekend in Tijuana, she gets in real trouble. To Sofi's shock, the border patrol says that her green card is counterfeit. Until her parents can sort out the paperwork and legal issues, Sofi is stuck in Mexico.

In the meantime, Sofi's parents arrange for her to stay with long-lost relatives in rural Baja. It's bad enough that Sofi has to miss senior prom and even graduation, but her aunt, uncle, and cousins live on a ranch with no indoor plumbing! As the weeks pass, though, 
she finds herself adapting to her surroundings. Sofi starts helping out on the ranch, getting along with her bratty cousins, and she even meets a guy with more potential than anyone from school. Through the unexpected crash course in her heritage, Sofi comes to appreciate that she has a home on both sides of the border. (Alegria, n.d.)

As the description reveals, the novel reverses the South to North immigration path, showing that migrations are multidirectional. In California, a great flow of people (many of whom are young adolescents) cross to Mexico in search of 'an experience'. Alegria narrates the story of Sofi Mendoza, a young Chicana, who crosses to Rosarito on a partying 'rite of passage' with a group of friends without her parents' permission. On her way back home, she is stopped at the border and is not allowed back into the United States, as she finds out she is not legally a US citizen, which renders her 'nationless, identityless'. This episode turns the adolescent's rite of passage into a journey of self-awareness and awakening of understanding of her ethnicity, social status, family origins, etc. The experience changes Sofi's conception of Mexico and the United States. The vicissitudes she experiences serve as the moral of the novel, which aims at raising consciousness among young Chicanos/as and Latinos/as (and other readers) of the causes of immigration, reclaiming Chicanos' complex cultural heritage, and making young adults aware of the real implications of the 'American Dream'.

In Sofi's 'nightmare', she discovers “poverty, physical danger in the crossing and immigration laws" (Cummins, 2013: 63). In this sense, I find it interesting to observe the strategies the novel uses to make the young readers empathize with a reality they reject, and learn about the border and Mexico from a the standpoint of the Other, the marginalized, which in this case, is Mexico. For this, I will point out the ways the girl experiences and depicts Mexico, the United States, and the border as a physical line and as a state of mind. For the first time in her easy life, Sofi is conscious of the notion of 'illegality' and marginality, and of her identity.

The novel opens up with a journey South, from the United States to Mexico, a primarily frivolous act but one that breaks the notion that describes the United States-Mexico border movement as unidirectional, from the South to the North. Following scholar Neil Campbell's idea of the construction of the North American West and its borders as a rhizomatic process, where diverse movements from East to West, North to South, and vice versa occurred (2008), the novel depicts the United States-Mexico border as a bidirectional bridge. People, goods, and ideas cross from one side to the other and nurture both sides, creating a rich, hybrid space. The young protagonist's evolution into conceiving herself as a hybrid being reinforces the idea of the need that both parts of this supposedly irreconcilable space, the border, have of the other. Since "statescraft" (Autcher, 2013), or the need of the other for the creation of the notion of the state, is dual (Mexico and the United States base the definition and construction of this "statehood" on the existence of the border and its symbolic meaning), Sofi 
understands the importance of her heritage (Mexican) and her everyday reality (American) for the completion of her identity.

At the outset of the novel, the two countries/categories are experienced as irreconcilable for the girl, who has grown up believing Mexico was 'the other side', an alien territory for her. The novel's clear thematic two parts correspond to two opposing moments in the evolution of the girl's attitude toward Mexico. Her first, unconscious, frivolous approach to the country is as 'not-her-own', as a partying site. In this phase, Sofi is described as completely unaware of the social differences between the two countries, the cultural specificity of Mexico, and the intricate connection that her family and she have to it. Finally, at the end of the novel, the girl, having been forced to live in Mexico, learns how to appreciate the country and its idiosyncrasy, develops empathy for those who cross to the North in search of a better life, and understands she is a mélange of cultures and different sociohistorical realities. The process to this self-acquaintance and concomitant appreciation of Mexico and its people and culture is a transitional period, a process of acknowledging her historic and cultural self, an amalgamating moment, reminiscent of the dual, hybrid nature of the border. Her process of crossing from one reality to the other is equated to her assimilating her obviously border identity and complexity. Thus, Sofi's process of 'identitycraft' starts when she is described as follows:

Although Sofi had been born in Mexico, she didn't have a Wikipedia knowledge of the place. She'd been three when they left Tijuana. Her mother was from Mexico city, way down in the South of the country, the faded square photographs of her mother's family were totally foreign to her. Olivia and Taylor knew this, but that didn't stop them from asking. It drove Sofi crazy, because her friends had vacationed in Mexico countless times before, while Sofi had never been back. They probably knew more about the country than she did. Their persistent grilling made her uneasy. It made Sofi feel different, and that wasn't cool. Not that they ever said that; but it was implied, which was kind of worse. (Alegria, 2007: 2)

These words, at the beginning of the novel, when she is preparing for her partying trip to her home country, reveal that Sofi not only does not feel part of Mexico or Mexican culture but also considers it an indicator of her difference from the rest of the group (of a negative difference, in fact), which makes her feel uneasy. However, at the beginning of the trip to Mexico, she develops a hint of guilt (for having lied to her parents and for not understanding her connection to this new-to-her space). The frivolous knowledge that her friends have of the country as a vacation space depicts the US adolescents' lack of information of their neighboring country's social reality. The South, for them, is the exotic Other, conceived as a site of amusement, a space which they consider devoid of a social situation, where everything is possible. This is what they see: 
The street was clogged with vendors tempting clients with their wares. "Tacos!! Chicle!", "Very cheap!" Their voices blended together like a song. Women with long dark hair sold silver necklaces, bracelets, and earrings displayed on velvet-covered tables. Kids with sad gazes sold gum, wooden snake toys, or beaded jewelry. Indigenous women with long thick braids and dark shawls pushed vending carts under which babies slept. Tourist shop after tourist shop sold the exact same merchandise; hand-women hammocks, colorful serapes, corny T-shirts with pictures of naked girls or lewd jokes, Aztec artifacts, and even Mexican jumping beans! (Alegria, 2007: 27)

The homogenization and reification of the country, reinvented and represented in the form of tourist souvenirs, exemplify Sofi's friends' gaze when they visit Mexico. These souvenirs represent what bell hooks denominates the "commodification of Otherness", where "ethnicity becomes spice, seasoning that can liven up the dull dish that is mainstream white culture" (1992: 22). In contrast to the assumption that everything in Mexico seems exotic, spicy and tourist oriented, the following description of the border shows traces of imminent change in Sofi's perception of the existing dividing line/reality as a darker, dirtier, violent space. This use of the border as a hyper-transited space, where people face violence and dirt predicts what will occur to the girl: she will be stuck in (the real) Mexico and trapped in her ambiguous and unknown-to-her identity:

Traffic at the border was at a definite standstill. It seemed like everyone in Mexico was trying to get out. Smog greeted them like a dingy, unwelcome guest as they approached TJ. Taylor's thigh bounced nervously. She kept checking the rearview mirror, making sure the dog was still asleep. Indigenous women came by with groups of little children, weaving between the cars. The children were juggling balls or begging for change. Men in floppy straw hats came by selling hammocks, Powerpuff Girl shoe racks, T-shirts, and Popsicles. It was hot and the air was thick and sticky. US border agents in dark blue uniforms patrolled between cars with their fierce-looking Labradors sniffing for drugs. (Alegria, 2007: 61)

In Mexico, as Cummins states (2013: 63), Sofi discovers poverty and a humble way of life. She embodies the recurrent intergenerational gap that exists in young adult novels and is unaware of other realities and living conditions. Her forced stay at her uncle and aunt's rancho shows that what are ordinary comforts for her, such as cable TV or Internet, are not intrinsic to the human condition. Moreover, she once visits a migrant camp with a priest, where she discovers real poverty. After the visit, she states, in quite a 'morally, and even ideologically conscious' way,

"It always breaks my heart when I come out here," the priest said in Spanish. "There's no running water or electricity. The people of these migrant camps are the invisible 
members of our society." Sofi nodded, overcome with sadness. "They come from small villages in Oaxaca and Chiapas. They speak little Spanish and many have never been to school." $[\ldots]$

Sofi realized that this was another world, one she never knew existed. Was this how the rest of the world lived? Sofi thought about her family's town house and the immaculately kept yard, her state-of-the art school, and her comfortable bedroom. Why do I live there and have everything and more? Why do some children go hungry while others pick and choose what they want on a whim? (Alegria, 2007: 152)

Facing this reality, the girl learns to appreciate the value of things, and she starts thinking about her parents' effort to provide her with a comfortable life. These thoughts are used by Malín Alegria with an obvious pedagogical purpose, as many adolescents who were born in the United States or arrived in the country at a very early age are unaware of their parents' previous life and harsh situation.

Sofi regards the United States, in contrast, and her easy, comfortable life as 'the natural state of things'. Her frivolous, politically unaware friends, her constant worry about beauty and relationships, and her desire to party and 'enjoy life' are, to Sofi, the only issues worth worrying about. The United States is, for her, not only her home country but also the natural space where this reality can occur. She associates this social space, where her "stories-so-far" (Massey, 2005) have occurred, to her personal, natural, seemingly inherent reality. Mexico, in contrast, is regarded by her as a denigrating, poor, and almost uncivilized space, devoid of her stories and recollections, an alien space. In Doreen Massey's words,

[o]ne way of seeing "places" is as on the surface of maps: [...]. But to escape from an imagination of space as a surface is to abandon also that view of place- if space is rather simultaneity of stories-so-far, then places are collections of those stories, articulations within the wider power-geometries of space. Their character will be a product of these intersections within that wider setting, and of what is made of them. And, too, of the nonmeetings-up, the disconnections and the relations not established, the exclusions. All this contributes to the specificity of place. To travel between places is to move between collections of trajectories and to reinsert yourself in the ones to which you relate. (2005: 130)

The girl's formation of her identity in the United States is/has been directly related to the "US-stories-so-far" (Massey, 2005), those which have given shape to her identity as a North American adolescent. However, Sofi's US stories-so-far are also based on exclusion and her forgotten stories related to Mexico. The erasure of these, and the voluntary adoption of only the US ones, have thus shaped the identity she suddenly feels crash when she faces her Mexican stories. Her lived experiences in Mexico and the construction of this new 
narrative in her life, shatter the foundations of her identity and lead her to make ends meet for the completion of her new, inclusive, binational, bicultural, border identity.

Before Sofi becomes acquainted with Mexico and her Mexican past, the United States, home to Sofi, represented her sole identity, the identity she fought to maintain and defend, in opposition to her parents', who suffered discrimination and a second-class existence:

Sofi looked at her mother with feelings of shame and pity. She couldn't help it. Her parents were fixated on the American dream and talked constantly about how America was the best country in the world. It was the only place where hard work and persistence actually paid off. It was nothing like Mexico, where politicians were crooks, cops abused their power, and if you were poor, there was no way to get ahead. They were so proud to live in America, yet when they interacted with Americans, they grew quiet and nervous. After fourteen years, her parents were still uncomfortable with their accents and lack of formal education. They tiptoed around their white employers, white neighbors, and anyone in an expensive suit as if they were God Almighty. [...] Sofi refused to be like them. She was just as American as her friends. (Alegria, 2007: 5-6)

However, and following the idea of Kristeva's need of the abjected, what is obvious from Sofi's description is that she constructs her idea of the United States in opposition to what she sees in Mexico. In this sense, her notion of what is good and bad follows the idea posited by Werner Sollors that "[e]thnic identity, seen this way, 'is logically and historically the product of the assertion that " $\mathrm{A}$ is an $\mathrm{X}$ because he is not a $\mathrm{Y}$ " - a proposition which makes it remarkably easy to identify Xness. By the same token, the definition of Xs as nonYs threatens to exaggerate their differences in such a way that if the Xs think of themselves as human, they may therefore consider the $\mathrm{Y} s$ as somehow nonhuman" (1995: 288). Likewise, the girl's understanding of her own identity (she is an American) is derived from the construction of the feeling of what she is not, rather than of what she is. In addition, her perception of her parents as what she is not (or does not want to be) responds to the clear generational gap in all cultures and environments, regardless of ethnic or national identity issues. The novel, markedly for young adults, expresses a feeling its readers may well understand and creates an empathic bond with them, which then integrates additional moral and ethical issues in the highly didactic discourse.

The novel shows the gradual recognition of the girl's complex identity, merger of two cultures, and mirror of the border identity derived from the fluid and amalgamating cultural relationship between her two original home nations. Sofi says:

"I don't know who I am anymore. I used to think I was just normal. You know-going to school, hanging out with my friends, and looking forward to college. But since I've been here, my whole world has turned upside down." Sofi grew quiet. Her heart squeezed. The 
border had taken away all the things she loved and valued, her parents and friends. (Alegria, 2007: 158)

The girl's gradual identification with her 'other' identity helps her finally accept her ethnocultural heritage and integrate the forgotten, excluded, neglected side of her family background. In a highly symbolic way, the border, the dividing line, the herida abierta (Anzaldúa, 1987: 3), the border that "had taken away all the things she loved and valued" helps reconstruct and make one of herself, to understand that "[she] was a border girl. Not fully American or Mexican. She was both, a bridge between cultures, the best of both worlds" (Alegria, 2007: 277).

\section{CONCLUSION}

Alegria's didactic purpose is materialized by the narration of this 'common Chicana's' quest for personal and cultural identity. The rite of passage Sofía goes through into her personal and moral maturity serves the author's goal of writing a novel for young adults with a purpose: that of creating "social responsibility", "caring and empathy", raising awareness of "social problems and social justice", promoting "historical consciousness and historical empathy" (Wolk, 2009: 664-668). The construction of a character that may be easily recognized by the target public of the novel, undergoing exceptional North to South adventure, helps the author introduce everyday life issues at the border, which many young Latinos/as (and others) may choose to reject or avoid seeing.

However, it is my view that the novel, categorized as Latino/a Young Adult Literature, addresses issues that may concern Latino/a young adults, young or US young adults, adults in general. It portrays a specific sociogeographical and cultural space, the US-Mexico border and the North of Mexico, about which young adults in particular, and readers in general, may be educated and informed. In this regard, Alegria's novel perfectly serves the purposes stated by Wolk. It uses narrative fiction to represent a specific space, which, however, is also global. It tackles issues and socio-personal realities which are site-specific but may be identified and empathized with globally. In this sense, it not only breaks the North/South and South/North dividing line and provides the border with an active and positive essence, but it also helps break the boundaries that the labeling of genres and works of art imply. Regardless of the fact that the characters, events and space of the novel are Chicano/a-specific, the novel serves the final purpose of holistically educating young adults in particular, and readers in general, through literature. 


\section{ACKNOWLEDGEMENTS}

This essay has been completed under the auspices of the research group REWEST financed by the Basque Government (Grupo Consolidado IT608-13) and the University of the Basque Country, UPV/EHU (UFI 11/06). The research carried for its writing has also been funded by the Spanish Ministry of Economy and Competitiveness (code: FFI20114-52738-P).

\section{NOTES}

1 Inverted single commas mine. I chose to include certain terms between inverted single commas with the purpose of questioning their meaning, use and implications, or for satirical purposes. Thus, these particular commas question the meaning and use of the term 'illegal'. The same pattern will apply to other terms that appear between these commas.

2 The Act included "(1) a systematic surveillance of the international land and maritime borders of the United States through more effective use of personnel and technology, such as unmanned aerial vehicles, ground-based sensors, satellites, radar coverage, and cameras; and (2) physical infrastructure enhancements to prevent unlawful entry by aliens into the United States and facilitate access to the international land and maritime borders by United States Customs and Border Protection, such as additional checkpoints, all weather access roads, and vehicle barriers" (Secure Fence Act, 2006).

3 "Operation Wetback, a national reaction against illegal immigration, began in Texas in mid-July 1954. Headed by the commissioner of the Immigration and Naturalization Service, Gen. Joseph May Swing, the US Border Patrol, aided by municipal, county, state, and federal authorities, as well as the military, began a quasi-military operation to search and seize all illegal immigrants" (Operation Wetback).

4 Even if there are today many authors, including Anzaldúa herself (Friends from the Other Side/Amigos del Otro Lado (1993), and Prietita and the Ghost Woman/Prietita y La Llorona (1995)), who address the existence and situation of the border from the perspective of young adults and children.

5 Even if I acknowledge that the difference between ethics and morality should be noted, I opted to include Scharf's standpoint on the "evolving moral conscience", particularly because it implies a personal development, which I think is present in Alegria's novel. Similarly, I am aware of the fact that authors such as Carol Gilligan strongly opposed Kohlberg's theory for been only-maleoriented. In the case of this novel, regardless of the fact that the protagonist is a young Chicana, I observe that her concerns at the beginning of the novel are similar those of teenagers in general. However, these concerns become secondary as her "moral conscience" evolves.

6 Most of these works present Latino/a characters and the issues they tackle are Latino/a-specific. However, there is no evidence that their target audience is specifically and only Latino/a.

\section{REFERENCES}

Alegria, M. (2006). Estrella's Quinceañera. New York, NY: Simon \& Schuster Books for Young Readers.

Alegria, M. (2007). Sofi Mendoza's Guide to Getting Lost in Mexico. New York, NY: Simon Pulse. Alegria, M. (2012). Border Town Series (Bordertown \# 1, 2, 3). New York, NY: Scholastic Books.

Alegria, M. (n.d.). Sofi Mendoza's guide to getting lost in Mexico. Malin Alegria. Retrieved May 5, 2016 from http://www.malinalegria.com/books/sofi-mendozas-guide-to-getting-lost-in-mexico. 
Anzaldúa, G. (1987). Borderlands. La Frontera. The New Mestiza. San Francisco, CA: Aunt Lute Books.

Anzaldúa, G. (1993). Friends from the Other Side/Amigos del Otro Lado. San Francisco, CA: Children's Book Press.

Anzaldúa, G. (1995). Prietita and the Ghost Woman/Prietita y la Llorona. San Francisco, CA: Children's Book Press.

Astor, A. (2009). Unauthorized Immigration, Securitization and the Making of Operation Wetback. Latino Studies, 7, 5-29.

Auchter, J. (2013). Border Monuments: Memory, Counter-Memory, and (B)Ordering Practices Along the US-Mexico Border. Review of International Studies, 39, 291-311.

Bureau of Transportation Statistics. United States Department of Statistics. (n.d.). Retrieved February 2, 2016 from http://transborder.bts.gov.

Campbell, N. (2008). The Rhizomatic West. Representing the American West in a Transnational, Global, Media Age. Lincoln, NE: University of Nebraska Press.

Campbell Naidoo, J. (Ed.). (2011) Celebrating Cuentos. Promoting Latino Children's Literature and Literacy in the Classrooms and Libraries. Santa Barbara, CA: Libraries Unlimited.

Chávez, L. R. (2003). Public Discourse, Immigration, and Control of the US-Mexico Border: Reflections on Jorge Durand and Douglas S. Massey's “The Costs of Contradiction: US Border Policy 1986-2000". Latino Studies, 1, 253-263.

Chávez-Palacios, E., Blanco, E. \& Graf, N. M. (2012). Cannabis, Culture and Anxiety: Attitudes of Mexican-American College Students on the Mexican-American Border. Journal of Rehabilitation, 78(4), 11-20.

Cummins, A. (2013). Border Crossings: Undocumented Migration Between Mexico and the United States in Contemporary Young Adult Literature. Children's Literature in Education, 44, 57-73.

Engdahl, S. (1980). Do Teenage Novels Fill a Need? In M. Lenz \& R. M. Mahood (Eds.), Young Adult Literature. Background and Criticism (pp. 41-48). Chicago, IL: American Library Association.

Holland, I. (1980). What is Adolescent Literature? In M. Lenz \& R. M. Mahood (Eds.), Young Adult Literature. Background and Criticism (pp. 33-40). Chicago, IL: American Library Association.

hooks, b. (1992). Black Looks. Race and Representation. Boston, MA: South End Press.

López, T. A. (2009). Reading Trauma and Violence in U.S. Latina/o Children's Literature. In M. Pagni Steward \& Y. Atkinson (Eds.), Ethnic Literary Traditions in American Children's Literature (pp. 205-239). New York, NY: Palgrave MacMillan.

Massey, D. (2005). For Space. London: Sage.

Migration Policy Institute. (n.d.). Retrieved February 2, 2016 from http://www.migrationpolicy.org.

Ortiz Cofer, J. (2003). Riding Low Through the Streets of Gold. Latino Literature for Young Adults. Houston, TX: Arte Publico Press.

Roxburgh, S. (1980). The Novel of Crisis: Contemporary Adolescent Fiction. In M. Lenz \& R. M. Mahood (Eds.), Young Adult Literature. Background and Criticism (pp. 141-147). Chicago, IL: American Library Association.

Scharf, P. (1980). Moral Development and Literature for Adolescents. In M. Lenz \& R. M. Mahood (Eds.), Young Adult Literature. Background and Criticism (pp. 101-106). Chicago, IL: American Library Association.

Secure Fence Act, H.R. 6061. (2006). Retrieved February 2, 2016 from http://www.gpo.gov/ fdsys/pkg/BILLS-109hr6061enr/pdf/BILLS-109hr6061 enr.pdf.

Sollors, W. (1995). Ethnicity. In F. Lentricchia \& T. McLaughin (Eds.), Critical Terms for Literary Study ( $2^{\text {nd }}$ ed.) (pp. 288-305). Chicago, IL: The University of Chicago Press.

Spener, D. (2004). Mexican Migrant-Smuggling: A Cross-Border Cottage Industry. Journal of International Migration and Integration, 5(3), 295-320.

Texas State Historical Association. (n.d.). Operation Wetback. Retrieved February 2, 2016 from https://tshaonline.org/handbook/online/articles/pqo01.

York, S. (2002). Children's and Young Adult Literature by Latino Writers. A Guide for Librarians, Teachers, Parents, and Students. Columbus, OH: Linworth Publishing.

Wolk, S. (2009). Reading for a Better World: Teaching for Social Responsibility with Young Adult Literature. Journal of Adolescent \& Adult Literacy, 52(8), 664-673.

(C) Servicio de Publicaciones. Universidad de Murcia. All rights reserved. IJES, vol. 16 (1), 2016, pp. 19-32 Print ISSN: 1578-7044; Online ISSN: 1989-6131 